\title{
PEMBINAAN TOLERANSI DAN PEDULI SOSIAL DALAM UPAYA MEMANTAPKAN WATAK KEWARGANEGARAAN (CIVIC DISPOSITION) SISWA
}

\author{
Yuni Maya Sari, Prodi PKn, SPs UPI, e-mail: indah_sarie55@yahoo.com
}

\begin{abstract}
ABSTRAK
Sikap toleransi dan peduli sosial terhadap sesama mulai menunjukkan gejala yang semakin memudar seiring dengan berkembangnya etnisitas, maka tentunya akan berdampak besar pada sebuah Bangsa. Membangkitkan kembali semangat toleransi dan peduli sosial dapat dilakukan melalui pendidikan karakter yang diimplementasikan dalam institusi pendidikan. Penelitian ini bertujuan untuk mengungkapkan dan mengetahui secara mendalam tentang realitas sikap toleransi dan peduli sosial siswa, proses pembinaan toleransi dan peduli sosial, faktor-faktor pendukung dan penghambat proses pembinaan, dan upaya pihak sekolah dalam pembinaan. Penelitian ini menggunakan pendekatan kualitatif dengan metode studi kasus dan data-data diperoleh melalui teknik wawancara, observasi, studi literatur, dan studi dokumentasi. Penelitian ini dilakukan di Sekolah Menengah Atas Negeri 4 Balikpapan Kalimantan Timur. Hasil penelitian mengungkapkan bahwa realitas sikap toleransi dan peduli sosial yang ditunjukkan siswa ditandai dengan menghargai pendapat orang lain baik, bersahabat tanpa membedakan suku dan agama, sikap saling menghargai, mengendalikan emosi, tidak mengejek teman, merancang dan melakukan berbagai kegiatan sosial, menghormati petugas-petugas sekolah, saling membantu, menjenguk teman yang sakit, dan melayat apabila ada orang tua siswa meninggal. Proses pembinaan toleransi dan peduli sosial siswa dilakukan melalui pembelajaran PKn di kelas, kegiatan ekstrakurikuler, dan pembiasaan di lingkungan sekolah. Faktor-faktor penunjang dalam proses pembinaan toleransi dan peduli sosial siswa yaitu kebijakan, pedoman kurikulum, kebersamaan warga sekolah, sarana dan prasarana, lingkungan, komitmen sekolah, lingkungan, dan kegiatan ekstrakurikuler. Sedangkan Faktor-faktor penghambat proses pembinaan toleransi dan peduli sosial yaitu masih kurangnya kesadaran dari diri siswa akan pentingnya bertoleransi dan peduli sosial dalam kehidupan, dan masih ada beberapa pihak yang tidak ikut berpartisipasi dan bekerja. Upaya yang dilakukan pihak sekolah dalam proses pembinaan toleransi dan peduli sosial siswa yaitu lebih maksimal dalam mengembangkan toleransi dan peduli sosial pada diri siswa di berbagai kegiatan, lebih terstruktur dalam penyusunan program, menghargai dan memberikan perlakuan yang sama terhadap seluruh warga sekolah, memfasilitasi kegiatan yang bersifat sosial secara lebih optimal, melibatkan pihak lain.
\end{abstract}

Kata kunci: toleransi, peduli sosial, watak kewarganegaraan.

\section{PENDAHULUAN}

Pendidikan adalah usaha sadar dan terencana untuk mewujudkan suasana belajar dan proses pembelajaran agar peserta didik secara aktif mengembangkan potensi dirinya untuk memiliki kekuatan spiritual keagamaan, pengendalian diri, kepribadian, kecerdasan, akhlak mulia, keterampilan yang diperlukan dirinya dan masyarakat. Di mana pendidikan mengacu pada berbagai macam aktivitas, mulai dari proses peningkatan kemampuan teknis (skill) sampai pada pembentukan kepribadian yang kokoh dan integral. Sebuah kegiatan yang mampu mengembangkan karakter anggotanya. Pendidikan pengembangan karakter dapat dilakukan melalui berbagai macam kegiatan, 
seperti penanaman nilai, pengembangan budi pekerti, nilai agama, pembelajaran dan pelatihan nilai-nilai moral dan lain-lain. Sebagaimana digariskan dalam Pasal 3 Undang-Undang Republik Indonesia Nomor 20 Tahun 2003 tentang Sistem Pendidikan Nasional (UU RI No. 20 tahun 2003 tentang Sisdiknas) :

Pendidikan nasional berfungsi mengembangkan kemampuan dan membentuk karakter serta peradaban bangsa yang bermartabat dalam rangka mencerdaskan kehidupan bangsa, bertujuan untuk mengembangkan potensi peserta didik agar menjadi manusia yang beriman dan bertakwa kepada Tuhan Yang Maha Esa, berakhlak mulia, sehat, berilmu, cakap, kreatif, mandiri, dan menjadi warga negara yang demokratis serta bertanggung jawab. (Departemen Pendidikan dan perpusatakaan, $2003: 62$ )

Belum tercapainya orientasi pendidikan yang mampu mendidik ternyata membawa dampak yang cukup besar bagi kehidupan. Para lulusan pendidikan saat ini seperti kehilangan jati diri bangsa yang dulu dikenal memiliki rasa toleransi dan peduli sosial yang tinggi dalam bermasyarakat. Hal ini kemudian diperparah lagi dengan serangan kebudayaan barat yang cenderung mendorong manusia untuk hidup individualis. Banyak fenomena degradasi moralitas generasi muda saat ini yang telah membuktikan bahwa sangat mudah mencari orang-orang yang pandai dan berilmu namun sangat sedikit dari mereka yang bermoral dan mampu menggunakan ilmu sebagai mana mestinya. Mereka hanya menggunakan ilmunya untuk mengejar kepentingan pribadi semata tanpa memperdulikan orang lain.

Sikap toleransi dan peduli sosial yang merupakan jati diri bangsa Indonesia kini mengalami penurunan. Rendahnya sikap toleransi dan peduli sosial terhadap sesama ternyata juga berimbas pada berbagai sendi kehidupan. Carut-marutnya moralitas anak bangsa bisa diamati dalam kehidupan seharihari. Seperti pemberitaan media tentang semangat toleransi dalam kehidupan berbangsa di kalangan pelajar semakin menurun. Kapus Penelitian \& Pengembangan Kebudayaan Balitbang Kemendikbud Hurip Danu Ismaji memaparkan bahwa Pada konflik sosial yang terjadi ditengah masyarakat, acapkali pelajar tak sekedar menjadi penonton tetapi sudah kerap ambil bagian secara aktif (http://www.poskotanews.com, 29 November 2013). Terbukti saat ini makin banyak pelajar terlibat dalam konflik sosial seperti tawuran, geng motor dan tindak kekerasan lainnya. Hidup di tengah-tengah perbedaan akan menyulitkan bagi individu yang tidak mampu menerima dan menghargai perbedaan tersebut.

Setiap individu di masyarakat memiliki ciri khas, latar belakang, agama, suku dan bahasa yang berbeda. Banyaknya perbedaan tersebut merupakan sebuah potensi yang dapat memicu konflik dan perpecahan di masyarakat apabila tidak mampu disikapi secara bijak. Sebagai contoh yang lain, banyak kerusuhan yang berbau SARA, Pertentangan antar kelompok masyarakat makin meningkat, kebencian yang makin kuat terhadap etnik tertentu, kebencian yang makin kuat terhadap sistem dan pelaksanaan program pemerintah yang dinilai sangat sentralistik dan otoriter, geng motor yang anarkhis, dan tawuran pelajar merupakan bukti nyata bahwa menghargai dan menghormati orang lain sudah menjadi sesuatu yang sangat langka di negara Indonesia. Pemberitaan media tentang tawuran antarpelajar di Indonesia semakin marak, terutama pada sepanjang tahun 2012. Komisi Nasional Perlindungan Anak (Komnas Anak) mencatat ada 229 kasus tawuran pelajar sepanjang Januari-Oktober tahun 2013. Jumlah ini meningkat sekitar 44 persen dibanding tahun lalu yang hanya 128 kasus. Dalam 229 kasus kekerasan antarpelajar SMP dan SMA itu, 19 siswa meninggal dunia (http://www.tempo.co/metro, 27/12/2013). Persoalan tawuran antarpelajar mengindikasikan bahwa kebijakan pendidikan karakter yang dibuat pemerintah belum terealisasi sebagaimana yang diharapkan. Sepanjang tahun 2013, banyak konflik sosial yang terjadi di Indonesia. Berdasarkan catatan Indonesia Police Watch (IPW) ada sekira 153 konflik sosial yang terjadi sepanjang tahun 2013. Ketua Presidium IPW Neta S Pane mengatakan, angka tersebut meningkat 23,7 persen jika dibandingkan dengan konflik sosial yang terjadi di tahun 2012. Konflik sosial di Indonesia, baik berupa 
tawuran, bentrokan massa maupun kerusuhan sosial (http://www.sindonews.com/read, kamis 02 Januari 2014).

Data teranyar yang lagi hangat-hangatnya, terjadinya kembali tawuran pelajar dan antar mahasiswa. Sejumlah mahasiswa Fakultas Hukum Universitas Kristen Indonesia (UKI) di Cawang, Jakarta Timur terlibat tawuran dengan mahasiswa dari Fakultas Ekonomi akhir tahun 2013 (http://news.detik.com, Selasa, 17/12/2013). Kemudian disusul di awal tahun 2014 terjadi tawuran antara siswa SMK Wiyata Kharisma dengan SMK Menara Siswa Bogor, Rabu (12/2/2014) siang menewaskan seorang pelajar yang terkena sabetan clurit saat terjadi aksi tawuran di jalan Raya Kemang-Bogor, Kecamatan Kemang, Kabupaten Bogor (http://www. tribunnews.com, 13 Februari 2014). Dampak dari tawuran itu, selain merusak fasilitas kampus, seorang peserta didik harus meregang nyawa sia-sia, sementara belasan lainnya luka parah. Ironis sekali pendidikan kita.

Fenomena-fenomena di atas merupakan bukti nyata dari pernyataan Thomas Lickona (dalam Akhmad Sudrajat, 2011), yang menyatakan bahwa ada 10 aspek degradasi moral yang melanda suatu negara yang merupakan tanda-tanda kehancuran suatu bangsa. Kesepuluh tanda tersebut adalah:

1. Meningkatnya kekerasan pada remaja.

2. Penggunaan kata-kata yang memburuk.

3. Pengaruh peer group (rekan kelompok) yang kuat dalam tindak kekerasan.

4. Meningkatnya penggunaan narkoba, alkohol dan seks bebas.

5. Kaburnya batasan moral baik-buruk,

6. Menurunnya etos kerja.

7. Rendahnya rasa hormat kepada orang tua dan guru.

8. Rendahnya rasa tanggung jawab individu dan warga negara.

9. Membudayanya ketidakjujuran.

10. Adanya saling curiga dan kebencian di antara sesama.

Meski dengan intensitas yang berbedabeda, masing-masing dari kesepuluh tanda tersebut tampaknya sedang menghinggapi negeri ini. Pendidikan karakter menjadi semakin mendesak untuk diterapkan dalam lembaga pendidikan kita mengingat krisisnya degradasi karakter atau moralitas anak bangsa. Di sinilah letak pentingnya menanamkan nilai toleransi dan peduli sosial pelajar melalui pendidikan karakter. Sehingga, masyarakat Indonesia akan mampu membuka visi pada cakrawala yang semakin luas. Maka sudah waktunya pendidikan mengambil alih kembali fungsinya dalam mendidik dan membentuk karakter manusia Indonesia yang berpedoman pada nilai-nilai luhur Pancasila. Kita tidak ingin degradasi moralitas bangsa khususnya kalangan pelajar semakin akut. Melalui pendidikan karakter yang diimplementasikan dalam institusi pendidikan, diharapkan krisis degradasi karakter atau moralitas anak bangsa ini bisa segera teratasi. Lebih dari itu, diharapkan di masa yang akan datang akan terlahirnya generasi bangsa yang memiliki karakter toleransi dan peduli sosial yang tinggi. Pembinaan nilai toleransi dan peduli sosial menjadi sebuah jalan keluar bagi proses perbaikan dalam masyarakat. Situasi sosial yang ada menjadi alasan utama agar pendidikan karakter segera dilaksanakan dalam lembaga pendidikan.

Upaya pendidikan karakter dalam mengembangkan nilai toleransi dan peduli sosial harus dilakukan dalam berbagai aktivitas dan lingkungan. Dalam lingkungan sekolah sikap toleransi dan peduli sosial menjadi nilai yang penting dan mendasar untuk dikembangkan. Sekolah disepakati sebagai bentuk sistem sosial yang di dalamnya terdiri dari komponen-komponen masyarakat sekolah dengan berbagai latar; ekonomi, lingkungan keluarga, kebiasaan-kebiasaan, agama bahkan keinginan, cita-cita dan minat yang berbeda. Dengan perbedaan-perbedaan ini tidak mustahil bila terjadi benturan-benturan kepentingan yang juga mengarah pada konflik-konflik kepentingan. Oleh karena itu diperlukan upayaupaya yang secara sengaja dan terus-menerus diarahkan untuk mengembangkan toleransi dan peduli sosial ini kepada siswa, sehingga mereka mendapatkan latihan-latihan dan pengalaman yang bermakna yang terkait dengan aspek-aspek tersebut, untuk selanjutnya dibawa dan dikembangkan dalam lingkungan masyarakat yang lebih majemuk. Dengan memperhatikan visi, misi, dan tujuan sekolah, pembinaan nilai 
toleransi dan peduli sosial ditandai dengan penekanan dimensi watak, karakter, sikap dan hal-hal lain yang bersifat afektif. Pendidikan karakter bukan sekedar memiliki dimensi integratif, dalam arti mengukuhkan moral intelektual anak didik sehingga menjadi pribadi yang kokoh dan tahan uji, melainkan juga bersifat kuratif secara personal maupun sosial. Pendidikan karakter menjadi sebuah jalan keluar bagi proses perbaikan dalam masyarakat. Situasi sosial yang ada menjadi alasan utama agar pendidikan karakter segera dilaksanakan dalam lembaga pendidikan.

Berdasarkan uraian tersebut, peneliti tertarik untuk mengkaji lebih dalam mengenai sejauhmana sekolah sebagai lembaga pendidikan formal menjalankan pembinaan pendidikan karakter dalam kaitannya dengan nilai toleransi dan peduli sosial siswa. Adapun masalah yang akan dikaji dalam penelitian ini difokuskan pada bagaimana proses pembinaan toleransi dan peduli sosial sehingga dapat membentuk dan memantapkan watak kewarganegaraan (civic disposition) siswa.

\section{METODE PENELITIAN}

Penelitian ini menggunakan pendekatan kualitatif dengan metode studi kasus, artinya peneliti mengungkapkan secara cermat suatu program, peristiwa aktivitas, proses atau sekelompok individu dan memahami kenyataankenyataan yang terjadi di lapangan sebagaimana adanya. Data dalam penelitian ini diperoleh melalui teknik wawancara, observasi, studi dokumentasi dan studi litertur. Wawancara ini dilakukan untuk memperoleh gambaran mengenai proses pembinaan toleransi dan peduli sosial dalam upaya memantapkan watak kewarganegaraan siswa yang di perkuat dengan data-data yang diperoleh dari analisis berbagai literatur dan dokumentasi yang relevan dengan kajian pembinaan nilai-nilai karakter dalam hal ini toleransi dan peduli sosial.

Lokasi penelitian ini di Sekolah Menengah Atas Negeri 4 Balikpapan Kalimantan Timur. Sumber data dari penelitian ini terbagi menjadi dua hal, yaitu meliputi data yang bersifat primer dan sekunder. Sumber data primer dalam penelitian ini adalah hasil dari wawancara dengan Informan diantaranya adalah
Kepala Sekolah, Wakil Kepala Sekolah Bidang Kurikulum, Wakil Kepala Sekolah Bidang Kesiswaan, Guru PKn, Pembina Ekstrakurikuler, dan siswa. Sedangkan sumber data sekundernya berupa buku, dokumendokumen, surat kabar yang terkait dengan materi pendidikan di pondok pesantren.

\section{HASIL DAN PEMBAHASAN}

Sekolah Menengah Atas Negeri 4 Balikpapan Kalimantan Timur merupakan sekolah perintis pendidikan karakter bangsa. Realitas toleransi yang ditunjukkan siswa-siswi SMAN 4 Balikpapan Kalimantan Timur diimplikasikan dalam wujud memberi kesempatan teman mengutarakan pendapat, menerima pendapat; kritik; dan saran dari orang lain, bersahabat tanpa membedakan suku; ras; agama; dan golongan, menghargai dan menghormati orang lain yang berbeda agama; suku; ras; dan golongan, mengendalikan emosi; menghindari kekerasan; dan mudah memaafkan. Apabila dilihat dari kehidupan di negara Indonesia yang plural ini, maka nilai-nilai karakter khususnya toleransi dan peduli sosial sangatlah tepat dibina pada siswa-siswi di sekolah dengan mewadahi siswa ke dalam sejumlah kegiatan yang dapat memupuk dan menumbuhkan adanya perasaan saling menghargai dan menghormati orang lain yang berbeda agama; suku; ras dan golongan serta menanamkan sikap peduli sosial pada diri siswa.

Sedangkan realitas perilaku peduli sosial siswa di SMAN 4 Balikpapan Kalimantan Timur dapat dikatakan sangat baik. Berdasarkan hasil penelitian, maka ditemukan bahwa berbagai kegiatan sosial yang dilakukan oleh siswa SMAN 4 Balikpapan Kalimantan timur baik di lingkungan sekolah maupun di luar lingkungan sekolah. Kegiatan sosial yang dilakukan antara lain menghimpun dana sukarela setiap ada siswa yang mendapat musibah, mengumpulkan sembako dan membagikan kepada masyarakat sekitar yang kurang mampu, menggalang dana membantu orang lain walaupun bukan bagian dari warga SMAN 4 Balikpapan, mengadakan sumbangan buku-buku layak baca, dan masih banyak kegiatan sosial lainnya. Dari pembahasan tentang realitas toleransi dan peduli sosial siswa 
SMAN 4 Balikpapan Kalimantan Timur, dapat dilihat terdapat perbedaan sikap toleransi dan peduli sosial antara kelas X dengan kelas XI dan XII, di mana sikap toleransi dan peduli sosial lebih terlihat pada siswa kelas XI dan XII karena siswa tersebut sudah mengalami proses pembinaan selama lebih dari satu tahun di sekolah. Sedangkan siswa kelas $\mathrm{X}$ yang merupakan perpindahan dari SMP ke SMA yang masih memerlukan adaptasi terhadap pembiasaan-pembiasaan yang dilakukan di sekolah tersebut dan masih perlu dibina secara optimal. Dengan adanya pembinaan toleransi dan peduli sosial pada diri siswa baru kelas X, maka terjadilah peningkatan sikap toleransi dan peduli sosial siswa yang disebabkan oleh program dan kegiatan pembiasaan yang dilakukan SMAN 4 Balikpapan.

Berdasarkan hasil penelitian yang dilakukan peneliti di SMAN 4 Balikpapan Kalimantan Timur, diketahui bahwa proses pembinaan toleransi dan peduli sosial melalui kegiatan pembelajaran, kegiatan ekstrakulikuler, dan pembiasaan di lingkungan sekolah dalam upaya memantapkan watak kewarganegaan (civic disposition) siswa SMAN 4 Balikpapan Kalimantan Timur sangat penting dilakukan pada diri siswa. Hal ini diindikasikan dari beberapa keterangan para guru yang mengemukakan bahwa dengan menggunakan beberapa langkah-langkah strategi yang memuat nilai-nilai, sikap, serta perilaku yang bermuara pada pembentukan toleransi dan peduli sosial siswa dapat memperkuat kecintaan kepada tanah air, bangsa, dan negara. Selain itu juga dengan pembinaan toleransi dan peduli sosial, siswa semakin memahami arti pentingnya bertoleransi dan peduli sosial di dalam kehidupan bermasyarakat, kekuatan hubungan antara manusia dapat dicapai, serta terciptalah kehidupan yang damai tanpa konflik-konflik sosial.

Pembinaan karakter yang terintegrasi dalam kegiatan belajar mengajar di kelas, artinya pengenalan nilai-nilai, kesadaran akan pentingnya nilai-nilai, dan pengintegrasian nilainilai ke dalam tingkah laku peserta didik melalui proses pembelajaran baik yang berlangsung di dalam maupun di luar kelas pada semua mata pelajaran. Dalam pembinaan toleransi dan peduli sosial pada diri siswa merupakan pengenalan terhadap nilai toleransi dan nilai peduli sosial, menumbuhkan kesadaran akan pentingnya bertoleransi dan peduli sosial, dan pengintegrasian nilai toleransi dan nilai peduli sosial ke dalam tingkah laku peserta didik melalui proses pembelajaran dengan menggunakan berbagai macam metode pembelajaran yang dapat menumbuhkan rasa saling menghargai, menghormati, terbuka terhadap pendapat orang lain dan kepedulian antar sesama. Berkaitan dengan pengintegrasian dalam kegiatan belajar mengajar, maka Kurniawan (2013:47) menegaskan bahwa:

Pendidikan karakter di lingkungan sekolah dapat diintegrasikan dalam pembelajaran pada setiap mata pelajaran. Materi pembelajaran yang berkaitan dengan norma atau nilai-nilai pada setiap mata pelajaran perlu dikembangkan, dieksplisitkan, dikaitkan dengan konteks kehidupan seharihari. Dengan demikian pembelajaran nilainilai karakter tidak hanya pada tataran kognitif, tetapi menyentuh pada internalisasi dan pengalaman nyata dalam kehidupan peserta didik sehari-hari di masyarakat.

Dalam proses pembinaan karakter khususnya toleransi dan peduli sosial diperlukan proses pembelajaran yang dapat menciptakan lingkungan belajar yang efektif sehingga hasil belajar siswa berada pada tingkat yang optimal. Dalam kegiatan belajar mengajar di kelas, pembinaan karakter toleransi dan peduli sosial dilaksanakan dengan menggunakan pendekatan terintegrasi dalam semua materi pembelajaran. Khususnya untuk materi pembelajaran Pendidikan Kewarganegaraan yang memang misinya adalah mengembangkan nilai dan sikap. Maka guru dapat melakukan modifikasi berbagai metode pembelajaran yang disesuaikan dengan penanaman toleransi dan peduli sosial pada diri siswa. Dengan demikian, proses pembinaan toleransi dan peduli sosial siswa melalui pembelajaran PKn di kelas dapat meliputi segala pengalaman yang diaplikasikan guru kepada peserta didiknya.

Berkaitan dengan proses pembinaan toleransi dan peduli sosial siswa SMAN 4 Balikpapan, pada prinsipnya guru selalu berusaha untuk mendekatkan materi yang 
dipelajari dengan berbagai realitas atau keadaan nyata yang sementara terjadi dalam kehidupan masyarakat khususnya yang dimiliki oleh siswa. Sehubungan dengan hal tersebut, maka Mulyasa (2002:100) mangatakan bahwa:

Proses pembelajaran pada hakikatnya adalah proses interaksi antara peserta didik dengan lingkungannya, sehingga terjadi perubahan perilaku ke arah yang lebih baik, maka dapat dikatakan bahwa sikap merupakan suatu kecenderungan yang bersifat negatif maupun positif seseorang untuk bertindak terhadap suatu objek yang dipengaruhi oleh faktor kognisi dan afektif individu terhadap abjek tersebut.

Berdasarkan hasil deskripsi penelitian ini, dapat dikatakan bahwa pemahaman dan strategi guru terhadap konsep toleransi dan peduli sosial yang dilakukan oleh guru PKn di SMAN 4 Balikpapan dalam proses pembinaan toleransi dan peduli sosial dalam upaya memantapkan watak kewarganegaraan cukup memuaskan. Guru memberikan pernyataan dan pertanyaan yang menggiring siswa untuk memahami dan mengaitkan materi pembelajaran dengan isu-isu aktual yang terjadi di dalam kehidupan masyarakat, memberikan berbagai pertanyaan yang sifatnya untuk memecahkan masalah, dan mencari alternatif jawaban, serta memberikan tugas melalui kelompok belajar yang berhubungan dengan materi yang sedang diajarkan dengan persoalan yang sedang terjadi di kehidupan masyarakat. Hal itu, semata-mata dilakukan oleh guru guna mendukung penguasaan materi toleransi dan peduli sosial untuk disampaikan kepada siswa.

Sebagaimana terungkap dalam hasil penelitian, bahwa pada proses pembinaan toleransi dan peduli sosial dalam upaya memantapkan watak kewarganegaraan (civic disposition) siswa SMAN 4 Balikpapan melalui pembelajaran PKn di kelas, ditemukan beberapa fakta bahwa guru dan sekolah telah mengintegrasikan nilai-nilai karakter ke dalam Kurikulum Tingkat Satuan Pendidikan (KTSP), Silabus, dan Rencana Pelaksanaan Pembelajaran (RPP) yang sudah ada. Guru PKn SMAN 4 Balikpapan senantiasa mempersiapkan RPP sebelum melaksanakan proses belajan mengajar.
Berkaitan dengan hal tersebut, Daryanto dan Darmiatun (2013:112) mengatakan bahwa:

Ada banyak cara mengintegrasikan nilai-nilai karakter ke dalam materi pembelajaran, antara lain; mengungkapkan nilai-nilai yang ada di materi pembelajaran, mengintegrasikan nilai-nilai karakter menjadi bagian terpadu dari materi pembelajaran, menggunakan perumpamaan dan membuat perbandingan dengan kejadian-kejadian serupa dalam hidup para peserta didik, mengubah hal-hal negatif menjadi nilai positif, mengungkapkan nilai-nilai melalui diskusi dan curah pendapat, menggunakan cerita untuk memunculkan nilai-nilai, menceritakan kisah hidup orang-orang besar, menggunakan lagu-lagu dan musik untuk mengintegrasikan nilai-nilai, menggunakan drama untuk melukiskan kejadia-kejadian yang berisi nilai-nilai, menggunakan berbagai kegiatan seperti kegiatan pelayanan, praktik lapangan melalui klub-klub atau kelompok kegiatan untuk memunculkan nilai-nilai kemanusiaan.

Berdasarkan hasil pengamatan langsung di lapangan, peneliti menemukan bahwa adanya kesesuaian antara RPP yang dibuat oleh guru dengan proses pelaksanaan pembelajaran di kelas. RPP yang dibuat oleh guru dijadikan patokan atau pedoman bagi guru dalam melaksanakan proses pembinaan toleransi dan peduli sosial siswa SMAN 4 Balikpapan. Guru PKn juga dalam pembinaan toleransi dan peduli sosial di kelas menggunakan beberapa metode pembelajaran yang dipilih dan digunakan secara bervariasi dengan mempertimbangkan tujuan pembelajaran. Seperti penuturan salah satu guru PKn (MP) bahwa metode yang digunakan dalam menunjang pembinaan toleransi dan peduli sosial yaitu seperti metode ceramah dengan menyisipkan pesan-pesan bertoleransi dan peduli sosial dalam kehidupan sehari-hari, kemudian tanya jawab, dan metode diskusi dalam tugas kelompok. Di mana yang menjadi faktor pertimbangan memilih metode-metode tersebut yaitu melalui diskusi siswa bisa mengasah diri untuk bagaimana cara bertoleransi, bagaimana cara berpendapat di depan umum, dan menerima pendapat dari orang lain, serta memiliki rasa kepedulian 
terhadap sesama. Jadi ketika ada di masyarakat siswa bisa menjadi warga negara yang baik dan mampu berpartisipasi secara aktif.

Berdasarkan deskripsi hasil penelitian diungkapkan bahwa Pembinaan toleransi dan peduli sosial siswa melalui kegiatan belajar mengajar di kelas dengan cara (1) Mengintegrasi nilai-nilai karakter ke dalam semua mata pelajaran khususnya PKn. (2) Guru mengajarkan toleransi dan peduli sosial dengan memberikan isu-isu aktual dan contoh-contoh konkrit yang terjadi di kehidupan masyarakat agar siswa lebih memahami di dalam mengaplikasikan nilai tersebut pada kehidupan sehari-hari. (3) guru menggunakan beberapa metode yang mendukung pembinaan toleransi dan peduli sosial diantaranya (a) metode ceramah untuk menyisipkan contoh-contoh aktual. (b) metode tanya-jawab untuk menanamkan rasa ingin tahu; komunikatif; tanggung jawa; dan kepedulian sosial, dan membentuk karakter peserta didik yang demokratis; pluralis; menghargai perbedaan pendapat; terbuka; dan humanitas yang tinggi. (c) metode belajar kelompok (pembelajaran kooperatif) agar materi yang dipelajari tidak hanya bersumber dari guru tetapi dari sumbersumber lain dan bisa belajar dari peserta didik lain, ide dan gagasan peserta didik dapat dikembangkan dan membandingkannya dengan ide-ide orang lain, peserta didik lebih respect pada orang lain dan menyadari keterbatasannya, menerima segala perbedaan (toleransi) baik dalam satu kelompok maupun kelompok lain, kemampuan sosial meningkat, hubungan interpersonal yang positifdengan peserta didik lain akan berkembang. Hal itu secara langsung melaksanakan transfer nilai-nilai karakter khususnya toleransi dan peduli sosial serta mendorong semangat kebersamaan pada diri siswa SMAN 4 Balikpapan sebagai warga negara Indonesia yang berada di dalam keberagaman agama; suku; ras; dan golongan. (5) Guru memberikan keteladanan secara langsung kepada siswa berupa sikap dan perilaku yang mencerminkan toleransi dan peduli sosial. Sehingga siswa dapat mencontoh sikap yang dicerminkan oleh guru di kelas.

Pembinaan karakter yang terintegrasi dalam kegiatan ekstrakurikuler, artinya berbagai hal terkait dengan nilai-nilai karakter diimplementasikan dalam kegiatan pengembangan diri melalui kegiatan ekstrakurikuler. Dalam pembinaan toleransi dan peduli sosial pada diri siswa melalui kegiatan ekstrakurikuler dapat dilakukan dengan cara mengimplementasikan nilai toleransi dan peduli sosial ke dalam berbagai kegiatan di luar kelas. Berkaitan dengan pengintegrasian melalui kegiatan ekstrakurikuler, maka Wibowo (2012:94) mengatakan bahwa:

Melalui kegiatan ekstrakurikuler dan kegiatan lain yang diikuti oleh seluruh atau sebagian peserta didik, dirancang sekolah sejak awal tahun pelajaran, dan dimasukkan ke dalam Kalender Akademik. Misalnya, kunjungan ke tempat-tempat yang menumbuhkan rasa cinta terhadap tanah air, menumbuhkan semangat kebangsaan, melakukan pengabdian masyarakat untuk menumbuhkan kepedulian dan kesetiakawanan sosial (membantu mereka yang tertimpa musibah banjir, memperbaiki atau membersihkan tempat-tempat umum, membantu membersihkan atau mengatur barang di tempat tertentu).

Berdasarkan hasil wawancara, observasi dan studi literatur diperoleh gambaran bahwa kondisi proses pembinaan toleransi dan peduli sosial dalam upaya memantapkan watak kewarganegaraan (civic disposition) siswa SMAN 4 Balikpapan melalui kegiatan ekstrakurikuler berjalan sangat baik dan memuaskan. Hal tersebut diindikasikan dari beberapa keterangan yang diungkapkan oleh sejumlah guru pembina ekstrakurikuler yang mengemukakan bahwa dengan kegiatan ekstrakurikuler yang dilaksanakan di sekolah dapat meningkatkan pengembangan pendidikan karakter khususnya nilai toleransi dan peduli sosial di kalangan para siswa terutama bagi siswa yang mengikuti kegiatan ekstrakurikuler tersebut. Hal ini sejalan dengan Peraturan Menteri Pendidikan Nasional Nomor 39 Tahun 2008 tentang pembinaan Kesiswaan. Pada pasal 1 menyatakan bahwa Tujuan pembinaan Kesiswaan:

(a)Mengembangkan potensi siswa secara optimal dan terpadu yang meliputi bakat, minat, dan kreativitas; 
(b)Memantapkan kepribadian siswa untuk mewujudkan ketahanan sekolah sebagai lingkungan pendidikan sehingga terhindar dari usaha dan pengaruh negatif dan bertentangan dengan tujuan pendidikan;

(c) Mengaktualisasikan potensi siswa dalam pencapaian prestasi unggulan sesuai bakat dan minat;

(d) Menyiapkan siswa agar menjadi warga masyarakat yang berakhlak mulia, demokratis, menghormati hak asasi manusia dalam rangka mewujudkan masyarakat madani (civil society).

Berdasarkan pernyataan di atas jelas bahwa kegiatan ekstrakurikuler merupakan kegiatan tambahan untuk membina siswa yang dilaksanakan oleh di sekolah di luar jam kurikulum inti. Kegiatan ekstrakurikuler di sekolah akan memberi banyak manfaat bagi siswa teritama memperkaya pengetahuan dan memperluas kemampuan. Berdasarkan deskripsi hasil penelitian, terungkap bahwa seperti yang diungkapkan oleh beberapa responden bahwa semua ektrakurikuler sebenarnya memberikan peluang dalam pembinaan toleransi dan peduli sosial siswa. Namun ada beberapa ektrakurikuler yang memang sangat-sangat memberi pengaruh besar terhadap pembinaan toleransi dan peduli sosial seperti diantaranya ekstrakurikuler FRM (Forum Remaja Muslim), UKS (Unit Kesehatan Sekolah), PMR (Palang Merah Remaja), dan Pramuka. Masing-masing ekstrakurikuler tersebut memiliki programprogram kegiatan sosial yang dilaksanakan baik di sekolah maupun di luar sekolah. Muatan nilai yang terkandung dari kegiatan ekstrakurikuler tersebut yaitu siswa dituntut untuk dapat saling bertoleransi antar umat beragama, berteman tanpa membedakan suku; agama; golongan; dan status sosial ekonami, saling menghargai satu sama lain, saling tolong menolong, dan peduli terhadap sesama.

Pembinaan karakter yang terintegrasi dalam pembiasaan di lingkungan sekolah, artinya perencanaan dan pelaksanaan pendidikan karakter pada diri siswa yang dilakukan melalui pengintegrasian ke dalam kegiatan sehari-hari atau pembiasaan di sekolah. Khusus pembinaan toleransi dan peduli sosial siswa melalui pembiasaan di lingkungan SMAN
4 Balikpapan Kalimantan Timur dilakukan dengan tiga pembiasaan yaitu pembiasaan rutin, pembiasaan spontan, dan pembiasaan keteladanan. Berkaitan dengan pembinaan melalui pembiasaan di lingkungan sekolah, Daryanto dan Darmiatun (2013:118) mengungkapkan bahwa:

Dalam lingkungan satuan pendidikan formal dan nonformal dikondisikan agar lingkungan fisik dan sosiokultural satuan pendidikan formal dan nonformal memungkinkan para peserta didik bersama dengan satuan pendidikan formal dan nonformal lainnya terbiasa membangun kegiatan keseharian yang mencerminkan perwujudan karakter yang dituju.

Dari pernyataan di atas jelas bahwa untuk mewujudkan pembinaan karakter pada diri siswa, sekolah wajib melakukan kegiatankegiatan keseharian yang berkaitan dengan karakter yang dituju. Sebab pembinaan karakter tidak cukup apabila hanya diajarkan di dalam kelas, pembinaan harus diteruskan dalam pembiasaan-pembiasaan di lingkungan sekolah agar siswa terbiasa mengaplikasikan nilai-nilai karakter ke dalam kehidupan sehari-hari. Berdasarkan hal tersebut maka dapat dikatakan bahwa pembiasaan di lingkungan sekolah yaitu pertama, pembiasaan rutin yang dilakukan SMAN 4 Balikpapan dalam hal ini yang berkaitan dengan pembinaan toleransi dan peduli sosial siswa yaitu salam senyum sapa, berdoa bersama sebelum dan sesudah pembelajaran di kelas, pemeliharaan kebersihan (Jumat bersih), pengumpulan serta pembagian sumbangan ke panti asuhan dan panti jompo, dan kegiatan infaq setiap hari jumat. Kedua, pembiasaan spontan yang dilakukan SMAN 4 Balikpapan yang berkaitan dengan pembinaan toleransi dan peduli sosial yaitu memberikan salam; senyum; sapa, membuang sampah pada tempatnya, mengatasi silang pendapat (pertengkaran), menjenguk teman yang sakit, kesetiakawanan sosial, dan anjangsana. Dan ketiga, pembiasaan keteladanan yang dilakukan SMAN 4 Balikpapan yang berkaitan dengan pembinaan toleransi dan peduli sosial yaitu guru berpakaian rapi, bekerja keras, berbahasa yang baik, memuji kebaikan dan keberhasilan orang 
lain, datang tepat waktu ke sekolah, perhatian terhadap peserta didik, menjaga kebersihan, dan berperan serta di dalam kegiatan sosial baik secara rutin maupun spontan. Di mana semua kegiatan baik rutin, spontan maupun keteladanan tersebut pada akhirnya bermuara pada penanaman dan pemantapan sikap toleransi dan peduli sosial pada diri siswa SMAN 4 Balikpapan sehingga nilai-nilai yang diajarkan akan melekat di dalam hati siswa dan akan tetap diaplikasikan ketika siswa terjun langsung kedalam kehidupan di masyarakat.

Dari hasil wawancara dan observasi terhadap beberapa responden dapat diketahuai bahwa terdapat faktor-faktor penghambat dan penunjang dalam melaksanakan pembinaan toleransi dan peduli sosial siswa di SMAN 4 Balikpapan Kalimantan Timur. Adapun faktorfaktor penunjang dalam proses pembinaan toleransi dan peduli sosial dalam upaya memantapkan watak kewarganegaraan siswa SMAN 4 Balikpapan yaitu (a) kebijakan dinas dan kepala sekolah, (b) pedoman kurikulum yang mengintegrasikan nilai-nilai karakter ke dalam perangkat pembelajaran, (c) sumber daya manusia yang secara keseluruhan berpartisipasi aktif dalam proses pembinaan baik melalui kegiatan belajar mengajar; kegiatan ekstrakurikuler; maupun pembiasaan di sekolah, (d) sarana dan prasarana, (e) lingkungan , (f) kebersamaan warga sekolah, (g) komitmen sekolah, (h) kegiatan ekstrakurikuler.

Sekolah sebagai organisasi kerja memerlukan kepala sekolah yang memiliki kemampuan managemen dan kepemimpinan yang tangguh agar mampu mengambil kebijakan, keputusan dan inisiatif untuk meningkatkan mutu sekolah. Peran kepala sekolah dalam membangun budaya sekolah berbasis karakter sangat menentukan, seperti melakukan pembinaan secara terus menerus dalam hal pemodelan, pengajaran, dan penguatan karakter yang baik terhadap semua warga sekolah. Sejalan dengan pernyataan di atas, Wibowo (2013: 119) menegaskan bahwa "Kepala sekolah memiliki peran yang kuat dalam mengkoordinasikan, menggerakkan, dan menyerasikan semua sumber daya pendidikan yang tersedia. Kepemimpinan kepala sekolah merupakan salah satu faktor yang dapat mendorong sekolah untuk dapat mewujudkan visi, misi, tujuan, dan sasaran sekolahnya melalui program-program yang dilaksanakan secara terencana dan bertahap". Dengan demikian dapat diartikan bahwa tindakan kepala sekolah adalah tindakan yang sangat fundamental dan menentukan eksistensinya sebagai pemimpin yang akan menyebabkan tindakan para guru yang berkarakter, staf berkarakter dan peserta didik yang berkarakter pula.

Pedoman kurikulum merupakan salah satu faktor penunjang proses pembinaan toleransi dan peduli sosial siswa. Salah satu yang menjadi penyebab pentingnya kurikulum dalam pendidikan karakter yaitu dengan kurikulum maka kegiatan pendidikan karakter akan terarah dalam mencapai tujuan yang telah ditetapkan. Seperti yang diungkapkan oleh Wibowo (2013:88) bahwa:

Manajemen kurikulum bukan hanya dibatasi dalam ruang kelas, tetapi menyangkut kegiatan pengelolaan di luar kelas, bahkan di luar lembaga pendidikan bersangkutan selama masih diprogramkan, yang terarah pada efektifitas pelaksanaan kurikulum. Agar pelaksanaan kurikulum bisa berjalan secara efektif dan efisien, pemerintah pusat telah mengeluarkan pedoman-pedoman umum yang harus diikuti oleh setiap institusi pendidikan, dalam menyusun perencanaan yang sifatnya operasional.

Artinya bahwa kurikulum yang harus dikembangkan oleh sekolah harus berpedoman pada pedoman kurikulum dari pemerintah pusat yaitu dengan mengintegrasikan nilai-nilai karakter ke dalam perangkat pembelajaran. Berdasarkan hasil wawancara dengan beberapa responden dapat diketahui bahwa SMAN 4 Balikpapan menggunakan kurikulum KTSP di mana nilai-nilai karakter sudah terintegrasi ke dalam semua mata pelajaran. Faktor pendukung lainnya yaitu kebersamaan warga sekolah yang secara keseluruhan berpartisipasi aktif dalam proses pembinaan baik melalui kegiatan belajar mengajar; kegiatan ekstrakurikuler; maupun pembiasaan di sekolah. Dalam hal ini yang dimaksud sumber daya manusia adalah seluruh warga sekolah yang turut berpartisipasi di dalam proses pembinaan toleransi dan peduli sosial 
siswa. Seperti yang diungkapkan oleh Daryanto dan Darmiatun (2013:38) mengenai sumber daya manusia, yaitu:

Masing-masing komponen sekolah, sejak dari kepala sekolah, guru, karyawan, siswa, orang tua/wali, dan juga masyarakat, memainkan peran yang penting bagi terwujudnya budaya sekolah. Mereka setiap hari harus mencurahkan dan memberi perhatiannya terhadap berlakunya nilai, norma, dan kebiasaan-kebiasaan terpuji di lingkungan sekolah. Terwujudnya budaya sekolah sepenuhnya berada di tangan mereka.

Pemaparan di atas menunjukkan bahwa tanpa adanya perhatian dan kolaborasi yang kuat dari seluruh sumber daya manusia yang ada di lingkungan sekolah, proses pembinaan toleransi dan peduli sosial akan sulit dijalankan, sekolah akan mengalami suasana kebingungan, warga sekolah akan mengalami ketidakjelasan arah dan tidak tahu ke mana arah yang harus dituju. Berdasarkan hasil wawancara dan observasi, maka dapat terlihat bahwa seluruh komponen/ sumber daya manusia di lingkungan sekolah sangat berpartisipasi dalam proses pembinaan toleransi dan peduli sosial siswa di SMAN 4 Balikpapan Kalimantan Timur. Proses pembinaan toleransi dan peduli sosial dalam upaya memantapkan watak kewarganegaraan (civic disposition) siswa SMAN 4 Balikpapan akan berjalan lancar jika ditunjang dengan sarana dan prasarana. Pengelolaan sarana dan prasarana dalam satuan pendidikan harus dilaksanakan. Sebagaimana ditetapkan dalam UU Sisdiknas No. 20/2003 Bab XII pasal 45 ayat 1 dijelaskan bahwa:

Setiap satuan pendidikan formal dan nonformal menyediakan sarana dan prasarana yang memenuhi keperluan pendidikan sesuai dengan pertumbuhan dan perkembangan potensi fisik, kecerdasan intelektual, sosial, emosional, dan kejiwaan peserta didik.

Pasal tersebut menegaskan bahwa pentingnya sarana dan prasarana dalam satuan pendidikan, sebab tanpa sarana dan prasarana maka pendidikan tidak akan berjalan secara efektif. Lingkungan merupakan salah satu faktor pendukung yang sangat penting di dalam proses pembinaan toleransi dan peduli sosial. Berdasarkan hasil wawancara dan observasi, dapat dikatakan bahwa lingkungan sangat memberikan pengaruh terhadap proses pembinaan karakter bangsa khususnya toleransi dan peduli sosial di SMAN 4 Balikpapan. Pernyataan ini sejalan dengan penuturan Kurniawan (2013:197) bahwa:

Sepantasnya lingkungan masyarakat yang baik dapat melahirkan berbagai kegiatan kemasyarakatan yang mendukung tumbuh kembangnya karakter, seperti peringatan hari besar keagamaan di surau, mushalla, atau masjid, taman pendidikan Al-Quran, kursuskursus keislaman, pembinaan ruhani, dan sebagainya. Dengan demikian, lingkungan masyarakat telah memberikan kontribusi positif bagi pendidikan yang ada di sekitarnya.

Selain faktor-faktor pendukung dalam proses pembinaan toleransi dan peduli sosial dalam upaya memantapkan watak kewarganegaraan siswa SMAN 4 Balikpapan, tidak dipungkiri bahwa terdapat pula faktorfaktor yang menghambat proses pembinaan toleransi dan peduli sosial siswa. Seperti yang pertama yaitu latar belakang siswa yang bermacam-macam dan kurangnya kesadaran dari diri siswa akan pentingnya bertoleransi dan peduli sosial dalam kehidupan sehari-hari, rasa malas dan sikap cuek serta mudah terpengaruh oleh teman untuk tidak ikut berpartisipasi dalam kegiatan-kegiatan sosial di sekolah. Kedua, masih ada beberapa pihak yang tidak ikut berpartisipasi dan bekerja sama dalam pembinaan nilai-nilai karakter.

Berdasarkan hasil wawancara dan observasi terkait dengan pembinaan toleransi dan peduli sosial siswa sebagai upaya memantapkan watak kewarganegaraan siswa SMAN 4 Balikpapan, sekolah sangat berperan dan berupaya dalam proses pembinaan karakter siswa terutama toleransi dan peduli sosial. Sekolah mengupayakan proses pembinaan dilakukan melalui berbagai kegiatan yaitu melalui kegiatan belajar mengajar di kelas, melalui kegiatan ekstrakurikuler, dan melalui pembiasaan-pembiasaan di lingkungan sekolah baik pembiasaan rutin; spontan; dan keteladanan. Hal tersebut sejalan dengan 
penuturan Wibowo (2013:15) bahwa dalam buku Pendidikan Karakter; Strategi Membangun Karakter Bangsa Berperadaban (2012), penulis telah menguraikan bahwa implementasi pendidikan karakter bisa dilakukan melalui: (a) terintegrasi dalam pembelajaran; (b) terintegrasi dalam pengembangan diri melalui kegiatan ekstrakurikuler; (c) terintegrasi dalam manajemen sekolah. Peran dan upaya pihak sekolah SMAN 4 Balikpapan dalam proses pembinaan toleransi di sekolah yaitu dengan menghargai dan memberikan perlakuan yang sama terhadap seluruh warga sekolah tanpa membedakan suku; ras; golongan; agama; status sosial ekonomi; dan kemampuan khas; bahkan kepada anak berkebutuhan khusus. Peran dan upaya pihak sekolah di dalam mengatasi hambatan dalam proses pembinaan khususnya untuk membangkitkan semangat kepedulian terhadap sesama dan saling menghargai yaitu dengan memfasilitasi siswa dengan kegiatan yang bersifat sosial lebih optimal, lebih banyak mengadakan aksi sosial baik di dalam sekolah maupun di luar sekolah, dan memberikan fasilitas untuk menyumbang baik itu sumbangan rutin seperti infaq jumat maupun sumbangan yang diperuntukkan kepada kejadian-kejadian bencana yang terjadi di lingkungan sekitar. Pembinaan nilai-nilai karakter tidak dapat dilakukan secara singkat, bahkan memerlukan waktu panjang dan berkesinambungan.

Berdasarkan penjabaran di atas mengenai upaya dan peran pihak sekolah dalam proses pembinaan toleransi dan peduli sosial, maka dapat disimpulkan bahwa peran dan upaya yang dilakukan pihak sekolah dalam pembinaan toleransi dan peduli sosial sangat besar. Hal ini terlihat pada upaya yang dilakukan pihak sekolah diantaranya (1) Lebih maksimal dalam mengembangkan toleransi dan peduli sosial pada diri siswa diberbagai kegiatan seperti kegiatan pembelajaran di kelas, kegiatan ekstrakurikuler, dan kegiatan pembiasaan di lingkungan sekolah. Di mana dahulu nilai-nilai karakter hanya diintegrasikan lewat mata pelajaran PKn dan Agama saja, sedangkan sekarang diupayakan pengintegrasian melalui berbagai kegiatan sehingga nilai-nilai karakter secara maksimal tersimpan dan tertanam dalam benak siswa. (2) Lebih terstruktur dalam penyusunan program, alokasi dana dan alokasi waktu serta melaksanakan program kegiatan yang bermuara pada pembinaan toleransi dan peduli sosial siswa (3) Menghargai dan memberikan perlakuan yang sama terhadap seluruh warga sekolah tanpa membedakan suku; agama; ras; golongan; status ekonomi. (4) Memfasilitasi kegiatan yang bersifat sosial secara lebih optimal seperti melakukan aksi sosial dan menyediakan fasilitas untuk menyumbang. (5) melibatkan pihak lain dan melakukan koordinasi yang berkesinambungan antara kepala sekolah dengan guru, guru dengan guru, guru dengan orang tua dan guru dengan siswa. (6) Peran dan upaya guru baik guru PKn maupun pembina ekskul dalam pembinaan toleransi dan peduli sosial dengan cara (a) menyampaikan dan memberikan materi yang berkaitan dengan proses pembinaan toleransi dan peduli sosial, (b) mengarahkan, membimbing siswa untuk mengikuti kegiatan ekstrakulikuler dan pembiasaan di lingkungan sekolah serta (c) membangkitkan rasa kepedulian pada diri siswa, semangat kebersamaan, cinta sesama dan kesetiakawanan sosial yang tinggi dalam diri siswa. Dengan segala upaya tersebut maka semua jenis hambatan yang menjadi kendala dalam proses pembinaan mudah diminimalisir.

\section{PENUTUP}

Berdasarkan beberapa temuan dalam penelitian yang telah diuraikan, terlihat bahwa realitas toleransi dan peduli sosial para siswa SMAN 4 Balikpapan Kalimantan Timur pada umumnya sangat baik. Hal ini sangat terlihat pada sikap dan perilaku siswa baik di dalam lingkungan sekolah maupun di luar lingkungan sekolah. Proses pembinaan toleransi dan peduli sosial dalam upaya memantapkan watak kewarganegaraan (civic disposition) siswa selalu berorientasi pada semangat kebersamaan, kepedulian, cinta sesama, dan cinta tanah air dalam kehidupan masyarakat di kota Balikpapan baik secara pribadi maupun secara universal dalam lingkungan sekolah. Sehubungan dengan kondisi lingkungan sekolah yang menampilkan kesadaran warga negara khususnya para siswa di SMAN 4 Balikpapan Kalimantan Timur yang bertempat tinggal di wilayah kota Balikpapan 
Kalimantan Timur, maka setiap warga negara Indonesia khususnya para siswa perlu menanamkan nilai-nilai kebangsaan yang bersifat nasional yang utuh terlebih sikap toleransi dan peduli sosial, guna memperkuat jati diri bangsa demi mewujudkan Negara Kesatuan Republik Indonesia yang merdeka, bersatu, berdaulat, adil, dan makmur yang berdasarkan Pancasila dan Undang-Undang Dasar 1945. Atas dasar itulah, maka proses pembinaan toleransi dan peduli sosial dalam upaya memantapkan watak kewarganegaraan (civic disposition) siswa di SMAN 4 Balikpapan khususnya merupakan suatu kewajiban yang perlu ditanamkan dan dikembangkan dalam kehidupan bermasyarakat, berbangsa, dan bernegara. Untuk membina toleransi dan peduli sosial dalam upaya memantapkan watak kewarganegaraan siswa SMAN 4 Balikpapan secara optimal perlu dilakukan berbagai program pembinaan diantaranya melalui pembelajaran PKn di kelas, melalui kegiatan ekstrakurikuler, dan melalui pembiasaanpembiasaan di lingkungan sekolah baik rutin; spontan maupun keteladanan.

Berdasarkan kesimpulan tersebut diharapkan kepada pihak sekolah dapat memfasilitasi pembelajaran yang sistematis, terpadu dan komprehensif untuk meningkatkan kualitas proses dan hasil pembinaan sehingga dapat meningkatkan kualitas pendidikan nasional untuk melahirkan sumber daya manusia yang bertoleran dan memiliki rasa kepedulian sosial. Dengan demikian toleransi dan peduli sosial yang diimplementasikan dalam KBM di kelas, kegiatan ekstrakurikuler, dan pembiasaan di sekolah dapat membantu dan mengarahkan siswa untuk menghayati dan menampilkan sikap serta tindakan positif sebagai perwujudan tindakan toleransi dan peduli sosial.

\section{DAFTAR PUSTAKA}

Daryanto dan Darmiatun, S. (2013). Implementasi Pendidikan Karakter di Sekolah. Yogyakarta: Gava Media.

Kurniawan, S. (2013). Pendidikan Karakter: Konsepsi \& Implementasinya secara Terpadu di Lingkungan Keluarga,
Sekolah, Perguruan Tinggi, \&

Masyarakat. Yogyakarta: Ar-Ruzz Media. Megawangi, R. (2004). Pendidikan Karakter

Solusi yang Tepat untuk Membangun

Bangsa. Bandung: BPMIGAS dan Energi. Mulyasa, E. (2002). Kurikulum Berbasis

Kompetensi. Bandung: Rosdakarya.

Peraturan Menteri Pendidikan Nasional

Republik Indonesia Nomor 39 Tahun 2008 Tentang Pembinaan Kesiswaan.

Sudrajat, A. (2011). Sepuluh Aspek Degradasi Moral dan Sebelas Prinsip

Pendidikan Karakter. [Online].

http://akhmadsudrajat.wordpress.com/2011/07/3

1/degradasi-moral-dan-prinsip-

pendidikan-karakter/. 28 Desember 2013.

Undang-undang Republik Indonesia Nomor 20

Tahun 2003 tentang Sistem Pendidikan Nasional.

Wibowo, A. (2012). Pendidikan Karakter: Strategi Membangun Karakter Bangsa Berperadaban. Yogyakarta: Pustaka Pelajar.

Wibowo, A. (2013). Manajemen Pendidikan Karakter di Sekolah. Yogyakarta: Pustaka Pelajar.

Pos Kota News. (2013). Menurun, Toleransi di Kalangan Pelaja .[Online]. http://www.poskotanews.com/2013/10/29/ menurun-toleransi-di-kalangan-pelajar/.

29 November 2013.

Tempo. (2013). Tawuran Sekolah Jakarta Naik 44

Persen.

[Online].

http://www.tempo.co/read/news/2013/11/20/ 083531130/Tawuran-Sekolah-Jakarta-Naik44-Persen. 27 Desember 2013.

News Detik. (2013). 2 Mahasiswa Fakultas di UKI Terlibat Tawuran. [Online]. http://finance.detik.com/read/2013/07/08/17141 0/2296001/10/2-mahasiswa-fakultas-diuki-terlibat-tawuran. 17 Desember 2013.

Tribun News. (2014). Satu Pelajar di Bogor Tewas Diclurit Saat Tawuran. [Online]. https://id.berita.yahoo.com/satu-pelajardi-bogor-tewas-diclurit-saat-tawuran185118516.html. 13 Februari 2014. 